\title{
Climate Change, Sea Level Rise, and Maritime Baselines: Responding to the Plight of Low-Lying Atoll States
}

\author{
Chris Armstrong and Jack Corbett*
}

\begin{abstract}
Predicted sea level rise caused by anthropogenic climate change threatens to drastically alter coastlines around the world. In the case of low-lying atoll states, it threatens to expunge them from the map. This potential scenario has engendered considerable discussion concerning the fate of climate refugees. Relatively little attention, however, has been given to the impact of sea level rise on existing maritime zones and how these zones, and the resources they represent, might continue to benefit displaced communities. This article builds on the small body of legal scholarship that has taken this matter seriously, to provide a normative analysis, based on principles of global justice, of the best ways of responding to the plight of atoll states. The article thus both extends legal scholarship by applying the principles of global justice to the problem of maritime boundaries, and contributes to the literature on global justice by investigating a salient but hitherto neglected case.
\end{abstract}

Over recent decades, the Maldives, a low-lying atoll nation in the Indian Ocean, has been seeking to secure its future in the face of sea level rises caused by anthropogenic climate change. Initiatives include the construction of an artificial island, Hulhumale, designed as a "Noah's Ark" for the Maldivian population in the event that existing islands are submerged beneath the rising sea, and the Great Wall of Male, a six-foottall seawall to protect the capital (see Gagain 2012). The motivation behind these unique feats of engineering is to secure the state against territorial extinction. However, these low-lying islands are more than just places in which people live; they are also "baselines" that create vast maritime zones and generate substantial income. In addition to losing their homes, the loss of maritime zones will result in the Maldivian population losing a source of their current livelihood (i.e., the ability to sell fishing rights) and potential future wealth (i.e., from deep-sea mining).

* Chris thanks the British Academy and the Leverhulme Trust for funding a Senior Research Fellowship (SRF $\backslash 170049$ ) on the topic of ocean justice. Jack thanks Tearinaki Tanielu for prompting him to think about this topic. He also acknowledges funding for this research provided by the Australian Research Council (DP160100897) and the British Academy (SRG1819 191216, supported by the Department for Business, Energy, and Industrial Strategy). 
The 1982 Law of the Sea Convention (LOSC) determines the maritime zones of sovereign states. There are several zones (territorial and contiguous zones, exclusive economic zones [EEZs], and the continental shelf), but they are all calculated from a single ambulatory baseline that is measured from the low-water mark (Article 5, LOSC). The LOSC assumes that sea levels will remain constant, but as climate change causes them to rise, this low-water mark will retreat, and with it, by negative implication (Caron 1990), the ambulatory baseline and the outer limit of maritime zones. Under the current LOSC, this will most likely alter existing maritime boundaries as areas of sea currently within EEZs, which include the waters within 200 nautical miles of the baseline, are reclassified as the high seas. The key issue is that states have exclusive rights to resources in these EEZs, whereas these rights are lost once the waters are reclassified as the high seas.

For coastal states, this will mean the potential shrinking of their borders and the loss of resources, either in the ocean or on the seabed. Under Article 121 of the LOSC, "rocks which cannot sustain human habitation or economic life of their own shall have no exclusive economic zone or continental shelf." As a result, low-lying atoll states like Kiribati, Maldives, Marshall Islands, and Tuvalu, which have some of the largest EEZs in the world due to their archipelagic geography (see Figures 1 and 2), will see their maritime zones expunged from the map by rising seas.

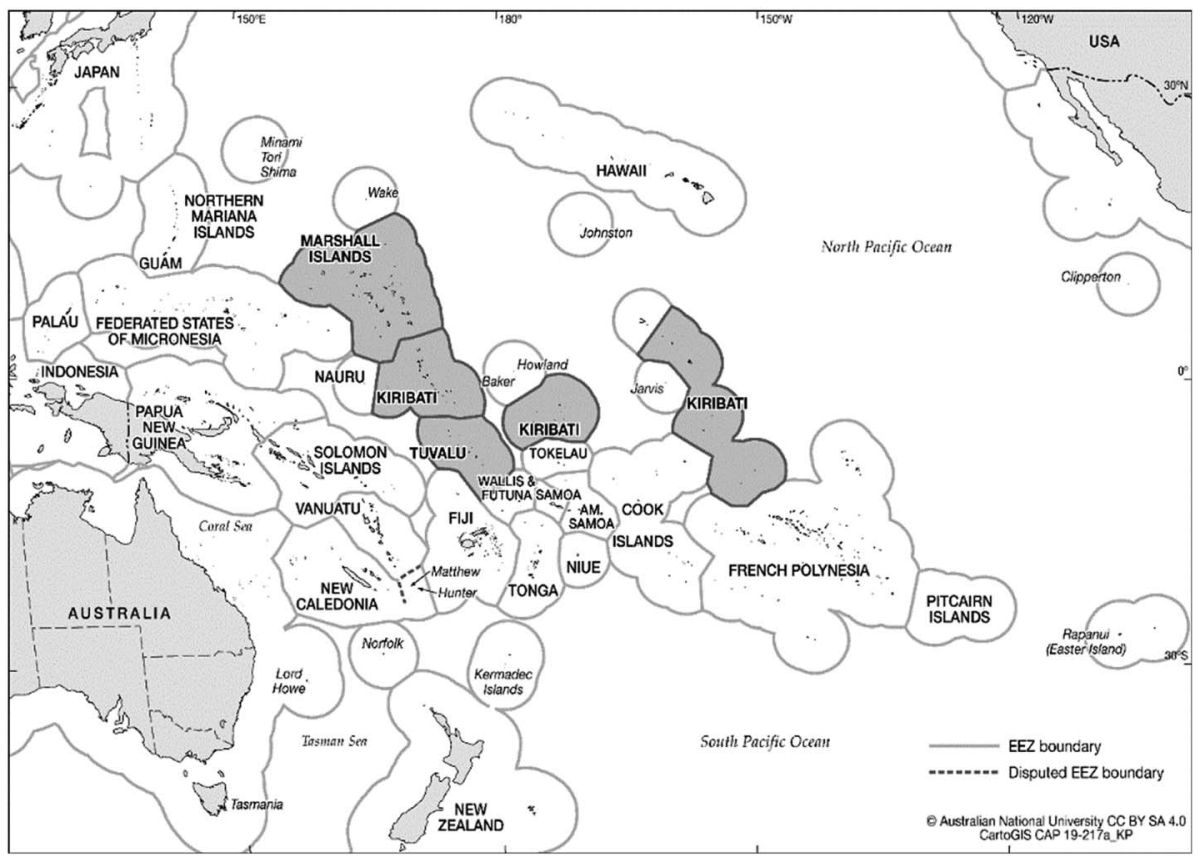

Figure 1

Exclusive Economic Zones in the Pacific 


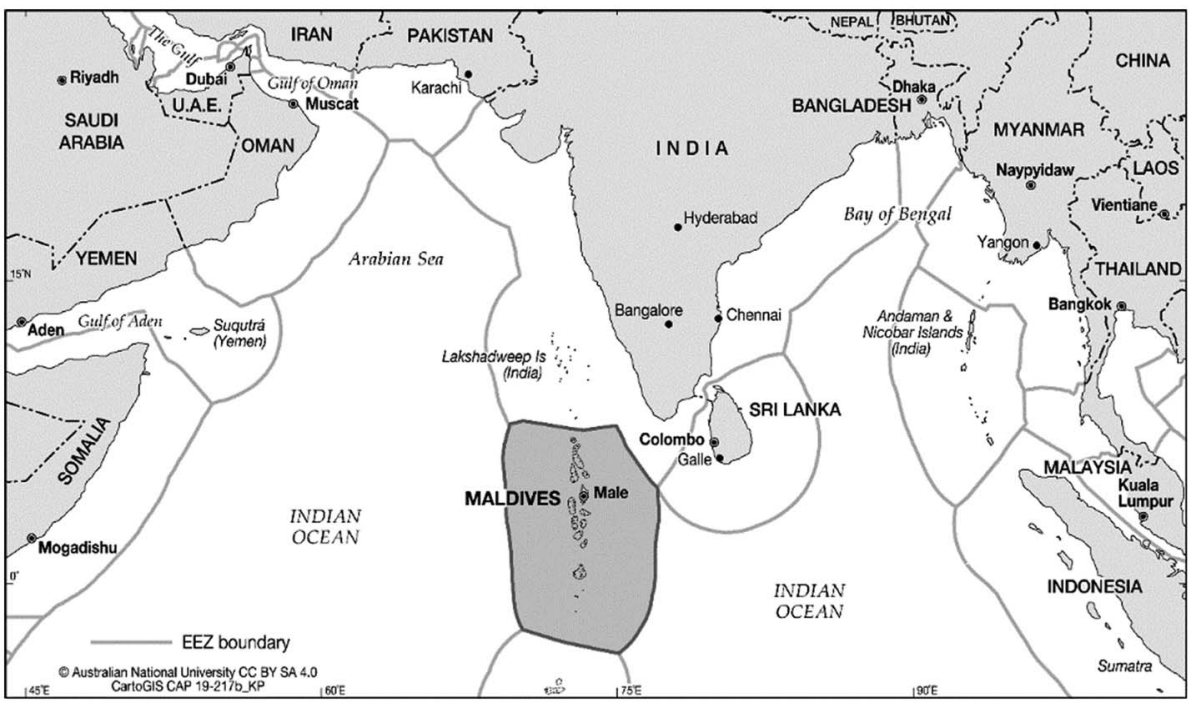

\section{Figure 2}

Exclusive Economic Zones in the Indian Ocean

The impact of sea level rise on severely vulnerable coastal communities has been studied extensively in the context of migration and the rights of climate refugees (see Eckersley 2015; Heyward and Ödalen 2016). This literature assesses, among other things, the most just means by which those dispossessed by climate change can find new homes. By and large, however, this work has not considered what rights, if any, displaced persons and communities should have to their maritime zones after their territories become uninhabitable (though see Ödalen 2014). Some political scientists have considered the impact of sea level rise on maritime zones, but their primary focus has been on potential disputes over the issue and whether these are likely to increase interstate conflict (e.g., Lusthaus 2010).

A small body of legal scholarship has taken these questions seriously (for review, see Stoutenburg 2015). Combined, this literature identifies four main options. Option 1 is to leave the LOSC as it is. This is the simplest solution, but it will severely disadvantage some states compared to others. Option 2 is to take a liberal interpretation of the LOSC. By using existing "straight baselines" provisions, some of the worst effects of rising sea levels can be mitigated for some states. This solution may work for affected deltas in Bangladesh, the Mekong, and so on, but it will not help low-lying atoll states that disappear entirely. The third option is to fix current baselines so that as coastlines shrink, maritime zones expand. This would not, however, help low-lying atoll states if territories disappear entirely. Finally, option 4 is to fix current baselines, as per option 3, and allow peoples from low-lying atoll states to retain their EEZs, even if the land territory has entirely disappeared. 
The problem legal scholars face is that they have not yet articulated a set of normative principles that would allow them to determine which of these options is the most legitimate and justifiable choice. This article fills this gap. We draw on the established global justice literature to argue that the most normatively justifiable solution, at least in nonideal circumstances, is probably to allow rights to EEZs to be retained even if these low-lying atolls become uninhabitable or submerged (i.e., option 4). This might be achieved in numerous ways, and questions about whether and how these rights might be passed down to descendants remain, but our goal is to show how prominent principles of global justice, derived from both minimalist and egalitarian views, can extend legal scholarship by providing a normative justification for this choice.

To substantiate these claims, the article unfolds over the following sections. Next, we review the legal discussion and the options proposed to resolve the problem. While this discussion is relevant to all coastal states, we pay particular attention to low-lying atoll states, as they stand to be the most severely affected by the loss of maritime zones. In the third section, we review the principles of global justice, which can give us traction in evaluating the various options from a normative point of view. In the fourth section, we apply these principles to the case under study. We conclude that fixing current baselines, perhaps at the same time as allowing for forms of de-territorialized statehood, looks to be the most attractive solution. In the final section, we engage with the views of atoll islanders themselves to investigate whether their preferred solutions diverge or converge with those we have suggested. One basis for confidence about our proposed solution, we will suggest, is that it is compatible with the claims made by many members of atoll island communities.

\section{Sea Level Rise, the LOSC, and the Problem of Maritime Zones}

The extent and time frame for climate-induced sea level rise are contested, but even the most conservative estimates foresee the displacement of hundreds of millions of people currently living in low-lying coastal areas, especially in places like Bangladesh and the Mekong delta. While much smaller in population, communities in the low-lying atoll states of Kiribati, Maldives, Marshall Islands, and Tuvalu will be the most dramatically affected, as even tens of centimeters of sea level rise have the potential to increase incidences of flooding and reduce the availability of potable water, effectively rendering these islands uninhabitable (Gagain 2012). The more pessimistic predictions of one- to two-meter rises by the end of the century would see the territories of these countries fully submerged.

The fate of these communities has generated considerable concern, with a burgeoning literature seeking to propose a set of principles and a framework for dealing with climate refugees (see Eckersley 2015). What this literature often overlooks, however, is that relative to the size of their territories, these states have disproportionately large maritime zones, which currently support their livelihoods via the sale of fishing rights in particular (see Table 1). The seabeds 
Table 1

EEZs and Low-Lying Atoll States

\begin{tabular}{lcccc}
\hline Country & Population & $\begin{array}{c}\text { Land Area } \\
\left(\mathrm{km}^{2}\right)\end{array}$ & $\begin{array}{c}\text { EEZ Approx. } \\
\left(\mathrm{km}^{2}\right)\end{array}$ & $\begin{array}{c}\text { Fisheries Contribution } \\
\text { as \% of GDP }\end{array}$ \\
\hline Kiribati & 110,000 & 726 & $3,500,000$ & 8.6 in 2014 \\
Maldives & 390,000 & 298 & 900,000 & 6 in 2009 \\
Marshall Islands & 75,000 & 720 & $2,100,000$ & 14.1 in 2014 \\
Tuvalu & 11,000 & 26 & 900,000 & 9.4 in 2014 \\
\hline
\end{tabular}

Source: World Factbook; FAO; Gillett (2016)

beneath these EEZs are also potentially rich in mineral resources that could provide considerable future revenue and spur the development of these states.

As sea levels rise, the LOSC as currently interpreted would see these EEZs, and the revenue they generate, diminishing and perhaps disappearing. The reason is that maritime zones are calculated from a single ambulatory baseline that is measured from the low-water mark. As coastlines retreat, maritime zones will shift, with the outer limits becoming reclassified as the high seas. This has considerable implications for all coastal states and especially those with large low-lying deltas. But the effects are perhaps even more significant for low-lying atoll states. Once low-lying atolls become submerged altogether, these maritime zones will cease to exist. Communities from low-lying atoll islands, who produce negligible emissions, thus face the prospect that they will lose both their homes and their livelihoods as a result of climate change.

This scenario was not foreseen at the time of the drafting of LOSC, and the Convention has not been altered to remedy this state of affairs in the years since the possibility has become apparent. One reason might be that each of the potential solutions is problematic in its own way. But it is also the case that the legal scholars who have been debating this situation for three decades have not yet articulated a set of normative principles that would allow them to determine which of these options is the most legitimate and justifiable choice. As it currently stands, the four options to resolve this problem are presented in the following sections.

\section{Option 1: Leave the LOSC as It Is}

This is the simplest solution from the legal point of view. But, as noted above, it will disadvantage some states over others, since the majority of states, even given significant sea level rises, will not lose their EEZs, whereas others will. There are two main ways in which this disadvantage might be mitigated. The first is that it is permissible under the current LOSC for states to protect or conserve their coastlines via adaptation techniques (but not by creating artificial islands; see Gagain 2012). So, for example, low-lying atoll states could essentially surround existing 
islands with seawalls or other structures, thus maintaining their baseline and EEZ. The most commonly cited example of this is the hundreds of millions of dollars Japan has spent to preserve the Okinotorishima rocks (see Houghton et al. 2010; Lisztwan 2012). The problem is that this is potentially incredibly costly and indeed inefficient: considerable resources would be diverted from other adaptation priorities in order to meet a legal requirement of the LOSC (Soons 1990). Gagain (2012) argues that these states instead should push for an expansion of the legal status of artificial islands for the purpose of maintaining maritime claims and statehood. But, as outlined under option 3, amending the LOSC is difficult and could create additional legal ambiguity.

A second solution would be to compensate these communities for the loss of their EEZs. But, while islanders have been pushing for "loss and damage" compensation as a result of climate change, the international community has shown no signs that it will open the door to these types of claims (Hoad 2016). Moreover, we suggest below that compensating for a loss is often an inferior policy when we possess the option of preventing that loss in the first place.

\section{Option 2: A Liberal Interpretation of Baselines}

Ambulatory baselines are calculated from the low-water mark, but in cases where the coastline is deeply indented, or there is a fringe of islands along the coast, a straight baseline can be drawn by joining appropriate points (Article 7, UNLOSC). One solution is therefore to adapt option 1 by building lighthouses and other installations on low-tide elevations to further facilitate straight baselines (Hayashi 2009). Busch (2018) goes further by arguing that a liberal interpretation of this provision would allow states with low-lying deltas, for example, in Bangladesh or the Mekong, to draw straight baselines without having deeply indented coastlines or fringe islands, thus mitigating the worst effects of sea level rise. Archipelagic states already make use of straight baselines joining the outermost points of the outermost islands (Di Leva and Morita 2008). This might be a reasonable course of action for low-lying delta communities, but, as Busch acknowledges, this solution will not work for states whose territories are fully submerged.

\section{Option 3: Fix Current Baselines So That as Coastlines Shrink, Maritime Zones Expand}

The advantage of this solution is that it produces few losers and has the potential to provide a degree of stability, at least with regard to disputed boundaries. However, this solution would arguably require either amending the LOSC or using another instrument, such as the Vienna Convention, that fixes boundaries between states (Lisztwan 2012) to essentially fix current baselines and so lock in the outer limits of maritime boundaries (see Caron 1990; Soons 1990). The LOSC was negotiated over decades as a "package deal," and amending it may require reopening a series of deeply contested issues at the same time. As a result, "at the present time there 
appears to be no desire in the international community to replace the LOSC, or even radically to amend it" (Churchill 2015, 45).

The kind of amendment under discussion would also potentially create a whole new set of legal ambiguities (for discussion, see Lisztwan 2012). For example, EEZs would no longer be restricted to 200 nautical miles from the baseline but would expand as the coastline shrinks, with newly submerged territory becoming part of the maritime zone. There is also conjecture about from when baselines should be fixed and for how long. Options include the date of entry of the LOSC or the date on which established boundaries are publicized on relevant charts and deposited with the United Nations Secretary General, as required by Article 16 of the LOSC (see Rayfuse 2009, 2010). Moreover, even if these issues were overcome, this solution still wouldn't account for low-lying atoll states, as the baseline, fixed or otherwise, still only applies to islands that remain above water (see Article 121 (3) UNLOSC).

\section{Option 4: Fix Current Baselines, as per Option 3, and Allow Displaced Peoples from Low-Lying Atoll States to Retain Their EEZs If the Territory Is Submerged Entirely}

Under this solution, maritime zones would be "fixed" in a legal sense, even if sea level rises cause the complete inundation of island territories. The outer edges of EEZs are already in a sense purely lines on a map, given that they do not correspond to physical features of the ocean. In this fourth solution, maritime zones would continue to exist and provide legal resource entitlements for atoll communities, even if they no longer correspond with any inhabited land. One thing to be said in favor of this solution is that it is the only one that deals with the case of lowlying atoll states without requiring them to build and maintain artificial islands.

The solution would, however, be relatively novel in allowing maritime entitlements to be held by people who no longer live in the vicinity. In principle, these rights might be held by scattered populations inhabiting countries many hundreds of miles away. There are in fact a number of scenarios in which maritime rights could be retained by the former inhabitants of atoll states. One possibility would be for "de-territorialized" states to merge with another state that would effectively assume the fixed EEZ and either pass on the revenue it generates to the displaced communities or treat it as payment for accommodating them. Alternatively, displaced communities could be ceded territory in another state but retain their fixed EEZ in their own right. Rayfuse $(2009,8)$ cites the example of displaced Icelanders being ceded territory in Canada during the 1870 s as a precedent for this kind of policy but acknowledges that the chances of a country ceding territory that is habitable or has sufficient resources to support a new state is probably low. A further option would be to grant displaced communities similar legal status as the Knights of Malta, the Papal See, governments in exile, or states that are not recognized by other states (such as Taiwan). People would retain their citizenship of atoll states, even if those states' land territories ceased to exist. Under such a 
scheme, a mechanism could be designed by which revenue from the EEZ continued to flow to them and their descendants wherever in the world they happened to live. Each solution is highly speculative, but it may be that some such innovation would be required to deliver on the entitlements of atoll islanders. In the next section, we investigate what leading theories of global justice might have to say about those entitlements.

\section{The Principles of Global Justice}

Aside from the practical complexities of each choice, a key challenge legal scholars face is to articulate a set of principles that would allow them to determine which of these options is the most justifiable from a normative point of view. For this, it is useful to turn to contemporary theories of global justice. Engaging with these views is a promising route to take here for several reasons. First, these theories perform a diagnostic function, allowing injustices to come into view and be closely dissected (Draper and McKinnon 2017, 2). Second, these theories have explicitly addressed the implications of their theories for concrete issues of climate justice, not least insofar as it is likely to impact core human rights (see, e.g., Caney 2010; Miller 2009; Moellendorf 2014). Third, they have clearly theorized the nature and content of the duties that outsiders can possess when it comes to climate-related mitigation and adaptation (Caney 2011; Miller 2009; Shue 2014). These theories have reflected extensively on the nature of our duties to people living in other societies and on the principles that ought to govern our actions in the international sphere.

Though it exhibits considerable complexity, the debate on global justice increasingly revolves around two key positions, which we can call minimalist and egalitarian, respectively (Armstrong 2012). The minimalist account suggests that all of us possess basic human rights, including socioeconomic rights, and that this can suffice to place duties on the shoulders of outsiders. Even if the citizens of any given state should look in the first instance to their own government when their basic rights have not been fulfilled, duties can and often do devolve to outsiders, for instance, in circumstances in which locals cannot fulfill their own rights, through no fault of their own (Miller 2007). One key duty that outsiders may possess, then, on the minimalist account, is a duty of assistance to help less fortunate societies establish and maintain decent and effective institutions, so that they are able to meet their citizens' basic human rights (Rawls 1999). A second duty will be an obligation to ensure that international institutions, and the global economy more generally, operate on fair terms. In contrast to egalitarian views (see below), the minimalist does not necessarily hold that the global economy has to offer each society strictly equal chances to develop, but it does need to ensure that relatively poor societies possess adequate opportunities to grow their way out of poverty (Miller 2007, 253). A global economy that failed to extend such opportunities to poor communities would be unjust. 
The egalitarian view, by contrast, is more demanding in its implications. For egalitarians, people should have (at least roughly) equal prospects in life, regardless of where in the world they happen to be born. One does not choose, after all, to be born in one place rather than another, and hence it is difficult, if not impossible, to explain to someone born in an impoverished community why his or her prospects in life should be so much less expansive than those of someone who has come to take for granted the advantages that come with being born in a wealthy country (Caney 2005; Moellendorf 2002). An egalitarian will certainly agree that we all possess basic human rights, including socioeconomic rights, and that protecting them can require us to place duties on the shoulders of outsiders. He or she will also agree that we need to make sure the international order offers adequate opportunities to all. But the egalitarian will want to go further than this. Opportunities should be not just adequate but equal, and making sure that everyone's basic human rights are met is a noble goal, but not the only goal, of global justice. A world in which everyone had a basic minimum would be an advance on our current world, but it would not exhaust the concerns of global justice. For the egalitarian, a priority will be the promotion of catch-up development, so long as this genuinely involves the expansion of the well-being of individual citizens across the developing world.

Each of these positions has implications for a world in which many people's livelihoods are jeopardized by climate change. On either a minimalist or egalitarian account, it would be unjust if climate change were to deprive people of the ability to make ends meet. Both minimalists and egalitarians have argued that, when it comes to the costs of dealing with climate change, we ought to ensure that the least advantaged do not end up picking up the tab. Darrel Moellendorf (2014), for example, has described what he calls an "anti-poverty principle," according to which the costs of dealing with climate change should not fall in such a way as to make it harder for poor communities to escape from poverty. The poor should be insulated from bearing climate-related costs, because they have another pressing social issue to deal with: the struggle to develop their way out of poverty. Though Moellendorf is primarily thinking of mitigation costs here, the same would be true in the case of adaptation costs: the poor should not bear the costs of adapting their lives to the changing circumstances brought about by climate change, and losses to their lands and livelihoods should be either avoided or compensated by those with a greater ability to make the relevant sacrifices.

Though Moellendorf is a global egalitarian, a rather similar conclusion has also been advocated by a prominent defender of the minimalist view. David Miller has argued that, however we allocate the costs of dealing with climate change, the first step in any just solution must be to absolve countries with endemic poverty of any responsibility to pick up the tab of dealing with climate change or its consequences (Miller 2009). Like Moellendorf, Miller plausibly argues that, since wealthy outsiders have the wherewithal to respond to climate change without plunging themselves into penury, there is no justification for requiring those currently in poverty to bear the costs. Climate change is not a problem that has 
been created by the global poor, and it is vitally important to ensure that it does not jeopardize their most basic rights (see also Shue 2014).

Elsewhere, Simon Caney has elaborated on the human rights most likely to be jeopardized by the consequences of unmitigated climate change. Most notably, climate change will represent a grave threat to many people's right to life (Caney 2010, 166-167). If people living in small island communities are not assisted in adapting to climate change-including, at the extreme, being given somewhere else to live - then their very lives will be in serious danger. But climate change will also jeopardize many people's right to subsistence (Caney 2010, 168169). This will be the case when sea level rises cause the salinization of agricultural land, making it difficult to meet basic nutritional needs. But it could also be the case if sea level rises nullify the legal right to exclusive fishing zones on which many people currently rely for their livelihoods. Many people in small island states rely on fishing both as their key source of protein and fatty acids and as a source of foreign income when fishing permits are sold to outsiders. If no alternative means exist of meeting either these nutritional needs or of securing vital foreign income, then the subsistence rights of these relatively poor communities will have been jeopardized. So, too, will their right to development more broadly, which both minimalists and egalitarians believe ought to offer them at least adequate opportunities to escape from poverty. For climate change to remove from small island states their ability to subsist and to develop would represent a considerable global injustice.

Finally, it is useful to consider the implications of these theories for the question of collective self-determination, since some of the options under review in this article seek in some sense to preserve the collective political life of atoll nations. Thus far in this section, our approach has largely fallen upon the rights to life, to subsistence, and to development. These rights are ultimately grounded in their importance to individual well-being. But the loss of atoll territories, and of maritime zones, also threatens to erode existing collective political projects, such as the commitment to live together as a community and to make collective decisions on resource use. Those commitments are undoubtedly highly valued by the communities in question, and their loss will add to the sense of dislocation experienced by islanders who are forced by sea level rise to abandon their traditional homelands. Indeed, it has been a prominent criticism of some liberal approaches to global justice that they are allegedly incapable of taking into account the sense of dislocation, the loss of a sense of place and also potentially of collective identity, that inundation could cause (Zellentin 2015). On some more communitarian-oriented visions of justice, this loss of a sense of place is actually one of the most grievous injustices associated with climate change and sea level rise (De Shalit 2011).

We would argue, however, that the theories of global justice under discussion do possess resources that enable them to capture these losses to collective self-determination. Miller's minimalist theory, for instance, foregrounds the significance of national self-determination, as well as the significance of stable national membership, to individual well-being (Miller 2007). Though Miller 
has not developed the implications of his theory for the case of the loss of atoll lands or maritime zones, the theory's emphasis on the value of collective selfdetermination would appear to lend support to solutions that seek to preserve at least a significant degree of self-determination rights for island communities. Other things being equal, a solution in which islanders retain decision-making power over maritime zones, and in which island communities are resettled collectively rather than individually, appear preferable from such a perspective. Accounts of global justice that take collective self-determination seriously have recommended collective, rather than individual, rights of resettlement for climate refugees (see, e.g., Nine 2010), and Miller's nationalist account may also find such solutions the most compelling. So, too, might multicultural theories of justice, which likewise foreground the significance of stable forms of cultural membership and the importance of mechanisms of political decision-making mapping where possible onto cultural membership (see, e.g., Kymlicka 1995).

Egalitarian accounts of global justice have often been more reticent about the value of national self-determination, and they have sometimes been criticized for failing to pay sufficient attention to the significance of a sense of home to climate refugees (Bell 2004). Nevertheless, a clear-eyed focus on the sources of well-being ought to recognize the significance of particular places, or particular resources, for people's projects and identities (Armstrong 2014). Egalitarian accounts can also recognize that a shared nationality is often important to people's well-being and can therefore agree that when we come to design political structures, we should pay attention to their likely effects on national cultures (Caney 2005, 182). As such, egalitarian theories, too, possess the resources to understand the loss of land, and of maritime rights, as a setback to the collective self-determination, and hence the well-being, of atoll peoples. On both theories, we have ample reason to investigate solutions to the plight of atoll islanders that seek to protect, rather than undermine, existing projects of collective self-determination, at least when doing so is compatible with broader goals of global justice.

\section{Global Justice and Maritime Baselines}

With these principles in mind, we can now evaluate the various options discussed earlier.

Option 1, to let EEZs simply disappear as a result of sea level rises, appears to place a serious obstacle in the way of small atoll states' ability to exercise their right to development. It is an open question whether we would object in the same way if the sinking communities were already wealthy or had an abundance of other development options. But for small atoll states, this is not the case. These communities are, for better or worse, highly dependent on income from their EEZs and have few other options if they want to escape from relative disadvantage. To be sure, some scholars of justice might be unpersuaded of the overall justification of attributing EEZs to states with coastlines. After all, some states simply lack coastlines in the first place, and coastal communities may not have done 
much to nurture or conserve the living and nonliving resources they are currently able to exploit by virtue of their EEZs (Armstrong 2017). Our first preference might be to see the oceans managed on some other basis, for example, as a huge global commons that would fairly share its benefits on a global scale. If maritime zones lost by one country were then collectively governed in the interests of global justice, that would in some respects be an attractive outcome. But things might look different if such an outcome is unlikely in the near future. In practice, lost maritime zones will more likely be incorporated into the high seas, where the governing principle for catching fish is "first come, first served." Moreover, if EEZs are likely to be a fixture for the foreseeable future, there does seem to be something objectionable about the fact that the vast majority of the more than one hundred states that have claimed EEZs will be able to retain exclusive rights over local resources even if sea level rises come to pass, whereas the few small island atoll states will lose theirs as a consequence of climatic changes for which they bear very little responsibility. Given that the sale of fishing rights forms a significant portion of the income of these small communities, and given that they have at present few other economic opportunities, the loss of these zones would represent a significant setback to their interests, which we ought to want to ameliorate.

One option, of course, is that small atoll states might be compensated for the loss of their EEZs. The United Nations already administers a number of schemes that could in principle channel funds to communities suffering significant "loss and damage" as a result of climate change (although those schemes are chronically underfunded at present). However, this does not appear to be an optimal solution even if compensation is likely to be forthcoming. Other things being equal, if we face a choice between causing harms or losses to people and then compensating them or not causing those harms and losses in the first place, we ought to take the latter option (Caney 2010, 172). One reason for this is that people are understandably wedded to their various plans and projects, and to avoidably set back those plans and projects will often be perceived as showing disrespect, even if compensation is then offered. Doing so will also undermine the autonomy of island communities. If offered a choice between becoming dependent on compensation from others and retaining their own rights to dispose of their existing resource rights as they see fit, they would likely choose the latter. For this reason, it is worth exploring scenarios under which those rights would somehow be retained.

Option 2, to allow states to retain EEZs by building out physical features so as to preserve their coastlines, appears vulnerable to a charge of arbitrariness. This potential solution would be helpful to communities that are able to maintain some, and perhaps most, of their land area, but it would do nothing to assist communities that stand to lose their entire land surface to sea level rises. Whereas a low-lying community like Bangladesh would continue to be able to benefit from marine resources in order to develop its way out of poverty-a valuable goal in its own right-a community like Kiribati, which was wholly submerged, would not be able to avail itself of this option. From the moral point of view, however, the losses experienced by individual I-Kiribati citizens appear just as significant, if not more so. 
Options 3 and 4, by contrast, appear more attractive from a normative point of view, because they avoid the relevant losses in development opportunities in the first place. Though they might be similar in their outcomes, however, option 4 (which retains EEZs even if island states are totally submerged) appears preferable to option 3 (which still requires some above-surface remnant of land according to which baselines can be calculated). Some international law scholars have suggested that the fixing of existing maritime boundaries should, in fact, be the default option and that achieving this outcome would not require radical reform of the LOSC (see Schofield and Freestone 2019).

Crucially, option 4 would allow rights to be retained even if the entirety of the land in question were submerged. There are a variety of ways in which this might be achieved, and much here will depend on what kinds of rights to relocation these territorially dispossessed communities possess. Within the literature on global justice and territorial rights, two main options have been discussed. According to the first, those made homeless by sea level rises have a right to be protected in much the same way as refugees: that is, they have an individual right to seek admission to a safe country elsewhere, which more fortunate states ought to respect (Heyward and Ödalen 2016). If we pursued this line, some way would need to be found for individual members of these island communities to legally retain a right to EEZs in the vicinity of their former homelands. There would need to be some kind of registry of former islanders, and some mechanisms by way of which to allow collective decision-making about the EEZ, and also some way of channeling any funds arising from it to former citizens of atoll states. The possession of rights over EEZs might even make admitting such migrants a more attractive prospect for receiving states, since the individuals concerned would have a guaranteed source of income for the future. Whether the relevant rights over EEZs would apply to their descendants too would be a further moral question. In principle, we might want to say that if their descendants came to enjoy decent opportunities in their countries of birth, their maritime entitlements could then lapse. But we will not seek to resolve this question here.

Alternatively, some political theorists have argued that territorially dispossessed communities have the right to relocate collectively, even if this means carving out some portion of an existing nation-state in which they might re-create a new homeland (Nine 2010; Stilz 2019). This is, perhaps, politically unlikely, since it would require at least one existing state-albeit, perhaps, a scantly populated one-to relinquish jurisdiction over some part of its territory. Though some political theorists believe they can be obliged to do so at the bar of justice-either because they possess "excess" territory or because they have remedial rights as a result of their contribution to climate change, or both-it would be somewhat surprising if such a solution were to come to pass. But if it did, it would allow a relatively simple retention of rights over an EEZ to an atoll community that would continue to live together in a new homeland.

In this section, we have considered the various options that appear to be open to us if we take the plight of atoll communities seriously. A recognition of 
the highly diminished development options of atoll communities, should significant sea level rises come to pass, requires us to consider such options seriously. From the point of view of global justice, we might well have reasons to believe that the system by which communities are allocated EEZs in the first place-on the basis of apparently arbitrary geographical features, such as the size of a country's coastline-leaves much to be desired. Certainly, schemes in which marine resources are shared more fairly are not difficult to imagine. But so long as the system of EEZs endures, we need to think carefully about the significant losses that inhabitants of small atoll states are likely to incur as a result of the loss of their present rights over living and nonliving resources off their coasts. At least in the case of communities with few other routes by which to escape relative disadvantage, we ought to want either to compensate for such losses or to explore creative legal means of avoiding them in the first place.

\section{What Do the Affected Communities Say?}

In this article, we have sought to provide normative guidance on how best to respond to the plight of atoll islanders who are likely to lose their maritime zones as a result of sea level rise, and we have done so by engaging with some of the bestknown theories of global justice. However, it is possible that those theories are revealing in some ways and obscuring in others. It might be argued that an adequate response to the injustices faced by members of particular communities will also engage with the lived experiences of those communities, as they grapple with global forces largely outside of their control (Ackerley 2018). We might argue that genuinely participatory approaches to climate justice, which focus on human agency rather than seeking top-down solutions, are hugely important too (Draper and McKinnon 2017, 3). In principle, the conclusions of 'top-down' theories of global justice might diverge from the 'bottom-up' demands of distinct communities making concrete claims of justice in a warming world. An alternative approach might begin with concrete practices of claims-making on the part of those dislocated-or potentially dislocated-by climate change (Arnall et al. 2019). This prompts us to ask, what, then, have the actual inhabitants of atoll states had to say about the optimal solutions to their plight?

We cannot hope in what remains to engage fully with the methodological questions raised by the bottom-up challenge. But we would claim that our proposals are broadly compatible, in fact, with the concrete suggestions of atoll islanders and their representatives. This is not to say that we do not have more to learn from paying attention to the lived experiences of atoll islanders, or to deny that global institutions seeking to mitigate or respond to climate challenges have often been lamentably out of touch with the ordinary lived experiences of people who are adjusting their lives to new climate realities across the world. But it is worth emphasizing that our proposals are in the spirit of the claims made by many atoll islanders. This suggests that the proposals we have endorsed in this article will be welcomed by most atoll islanders, rather than being perceived as a wrongheaded 
imposition on them. Proposals for climate mitigation, adaptation, and compensation are likely to be more successful when they connect with the actual desires, projects, and commitments of those people affected by them.

For a number of years, the island states of the Pacific region have argued that their maritime entitlements ought to be preserved, not reduced or lost as a result of sea level rise. That was made clear in the 2015 Taputapuatea Declaration, which emphasized the ocean-facing nature of Polynesian identity, an identity to which the peoples of Polynesia retain a "steadfast" commitment in the face of climate change. The Declaration emphasizes the ways in which climate change, to which the islanders have made a very small contribution, threatens the rights to survival and livelihoods of many people. It calls upon the international community to "permanently establish the baselines [of its maritime zones] in accordance with [LOSC], without taking into account sea level rise." It also calls upon the international community to establish a robust refugee protection regime for populations displaced as a result of climate change (Polynesian Leaders Group 2015, 3). Similarly, the 2018 Delap Commitment, signed by representatives from Kiribati, the Marshall Islands, and Tuvalu, among others, declares its intention "to pursue legal recognition of the defined baselines established under the United Nations Convention on the Law of the Sea to remain in perpetuity irrespective of the impacts of sea level rise" (Delap Commitment 2018, 3). The same intention has been declared by the Pacific Island Forum (Pacific Islands Forum Secretariat 2010).

Ordinary citizens, and social movements, have also recommended responses to the sea level challenge that empower island communities, rather than leaving them dependent on others for assistance. Most famously, Pacific Climate Warriors, a grassroots network of young Pacific Islanders, has become associated with the slogan "We are not drowning, we are fighting!" (McNamara and Farbotko 2017, 17). The Warriors have argued against seeing the inundation of island atoll states, and the relocation of islanders, as a foregone conclusion and have enjoined world leaders to take the serious mitigation actions that could avert such outcomes. As one representative has put it, "We don't deserve to lose our Islands and we will do what we must to ensure we won't" (Milan Loeak, quoted in McNamara and Farbotko 2017, 20).

But islanders also recognize that some level of inundation, and perhaps the total loss of some islands, may already be "locked in" because of our recent emissions path. In the face of such challenges, they have focused on adaptation measures that protect the connection to homeland and culture. Our suggestion is that the retention of maritime entitlements could be a key means of doing so even if islanders have no choice but to relocate. The retention of maritime rights could be a continuing source of collective identity for those who formerly inhabited the islands, a concrete connection to be retained even under a form of "de-territorialized" statehood. Maritime zones could represent a legal focus for the struggle to re-present islanders as active political agents rather than "passive victims" of climate change (Lazrus 2012, 292). Pacific Islander activists have argued that "it's not yet time to give up on the islands" and accept a new status 
as "stateless climate refugees" (Titifanue et al. 2017, 143-144). We are not suggesting, of course, that the retention of maritime zones could make up for the loss of conventional statehood (Ödalen 2014). Nevertheless, the retention of maritime zones could prove to be a key element in the retention of a shared legal and political identity for islanders faced with the prospect of inundation.

\section{Conclusions}

The LOSC and its use of baselines sought to account for the fact that coastlines are constantly changing as a result of natural processes. It did not anticipate, however, the possibility that climate change would cause sea levels to rise to such an extent that existing coastlines would be dramatically altered and low-lying countries would be submerged entirely. But, nearly four decades since it was ratified, four low-lying atoll nations-Kiribati, Marshall Islands, Maldives, and Tuvalu-face this bleak future. Not only will this result in the loss of islanders' homes and onshore livelihoods (i.e., tourism, especially in Maldives) but this will also result in their EEZs, which generate income via the sale of fishing rights, being expunged from the map. Such a dispossession would represent a considerable blow to countries that have contributed little to global emissions.

A small body of legal scholarship has debated this issue for some time. They have canvassed a range of options, from constructing artificial structures to amending the LOSC to fix baselines. But while each of these options has both drawbacks and merits, the lack of reference to a background theory of justice has meant that it is very difficult for these scholars to determine which option is the most preferable. This article fills this gap by applying principles of global justice, which have thus far tended to focus on climate refugees, to this case. We argue that while the institution of EEZs continues, the most normatively justifiable solution is to allow rights to EEZs be retained even if low-lying atolls become uninhabitable or submerged (i.e., option 4). This might be achieved in numerous ways, and questions about whether and how these rights might be passed down to descendants remain, but the principles of global justice, be they in a minimalist or an egalitarian interpretation, provide sound normative grounds for this choice. The alternatives, such as building seawalls or artificial islands or providing compensation, are problematic in their own ways. Retaining EEZs, by contrast, could provide a valuable focus for collective identity and political self-determination even if island states are wholly inundated.

Chris Armstrong is a professor of politics at the University of Southampton. His current work focuses on global justice, natural resources, and ocean justice. He is the author of Global Distributive Justice (2012), Justice and Natural Resources (2017), and Why Global Justice Matters (2019).

Jack Corbett is a professor of politics at the University of Southampton. He is the author of four books, editor of two volumes, and author of more than sixty 
articles and chapters. The majority of these works focus on small island states. He is co-editor of the Topics in the Contemporary Pacific book series with University of Hawai'i Press and of the Routledge Studies in Anti-Politics and Democratic Crisis, and he is deputy editor of the journal Small States and Territories.

\section{References}

Ackerley, Brooke. 2018. Just Responsibility: A Human Rights Theory of Global Justice. Oxford, UK: Oxford University Press.

Armstrong, Chris. 2012. Global Distributive Justice: An Introduction. Cambridge, UK: Cambridge University Press. DOI: https://doi.org/10.1017/CBO9781139026444

Armstrong, Chris. 2014. Justice and Attachment to Natural Resources. Journal of Political Philosophy 22: 48-65. DOI: https://doi.org/10.1111/jopp.12014

Armstrong, Chris. 2017. Justice and Natural Resources: An Egalitarian Theory. Oxford, UK: Oxford University Press. DOI: https://doi.org/10.1093/oso/9780198702726.001 .0001

Arnall, Alex, Chris Hilson, and Catriona McKinnon. 2019. Climate Displacement and Resettlement: The Importance of Claims-Making "from Below." Climate Policy 19: 665-671. DOI: https://doi.org/10.1080/14693062.2019.1570065

Bell, Derek. 2004. Environmental Refugees: What Rights? Which Duties? Res Publica 10: 135-152. DOI: https://doi.org/10.1023/B:RESP.0000034638.18936.aa

Busch, Signe Veierud. 2018. Sea Level Rise and Shifting Maritime Limits: Stable Baselines as a Response to Unstable Coastlines. Arctic Review 9: 174-194. DOI: https://doi .org/10.23865/arctic.v9.1162

Caney, Simon. 2005. Justice Beyond Borders. Oxford, UK: Oxford University Press. DOI: https://doi.org/10.1093/019829350X.001.0001

Caney, Simon. 2010. Climate Change, Human Rights, and Moral Thresholds. In Climate Ethics, edited by Stephen Gardiner, Simon Caney, and Dale Jamieson, 163-179. Oxford, UK: Oxford University Press.

Caney, Simon. 2011. Justice and the Duties of the Advantaged: A Defence. Critical Review of International Social and Political Philosophy 14: 543-552. DOI: https://doi.org /10.1080/13698230.2011.597246

Caron, David D. 1990. When Law Makes Climate Change Worse: Rethinking the Law of Baselines in Light of a Rising Sea Level. Ecology LQ 17: 621.

Churchill, Robin. 2015. The 1982 United Nations Convention on the Law of the Sea, in Oxford Handbook of the Law of the Sea, edited by Donald Rothwell, Alex G. Oude Elferink, Karen N. Scott, and Tim Stephens, 24-45. Oxford, UK: Oxford University Press.

Delap Commitment. 2018. Securing Our Common Wealth of Oceans. Majuro, Marshall Islands, March 2.

De Shalit, Avner. 2011. Climate Change Refugees, Compensation, and Rectification. The Monist 94: 310-328. DOI: https://doi.org/10.5840/monist201194316

Di Leva, Charles, and Sachiko Morita. 2008. Maritime Rights of Coastal States and Climate Change: Should States Adapt to Submerged Boundaries? Washington, DC: World Bank.

Draper, Jamie, and Catriona McKinnon. 2017. The Ethics of Climate-Induced Community Displacement and Resettlement. WIRES Climate Change 2017: e519. DOI: https:// doi.org/10.1002/wcc.519 
Eckersley, Robyn. 2015. The Common but Differentiated Responsibilities of States to Assist and Receive "Climate Refugees." European Journal of Political Theory 14: 481-500. DOI: https://doi.org/10.1177/1474885115584830

Gagain, Michael. 2012. Climate Change, Sea Level Rise, and Artificial Islands: Saving the Maldives' Statehood and Maritime Claims Through the Constitution of the Oceans. Colorado Journal of International Environmental Law and Policy 23: 77.

Gillett, Robert. 2016. Fisheries in the Economies of the Pacific Islands Countries and Territories. Available at: https://www.spc.int/sites/default/files/resources/2018-05/Gillett_16 _Benefish.pdf, last accessed June 16, 2020.

Hayashi, Moritaka. 2009. Sea Level Rise and the Law of the Sea: Legal and Policy Options. In Proceedings of International Symposium on Islands and Oceans. Tokyo Ocean Policy and Research Foundation.

Heyward, Clare, and Jörgen Ödalen. 2016. A Free Movement Passport for the Territorially Dispossessed, in Climate Justice in a Non-ideal World, edited by Clare Heyward and Dominic Roser, 208-226. Oxford, UK: Oxford University Press. DOI: https://doi .org/10.1093/acprof:oso/9780198744047.003.0011

Hoad, Darren. 2016. The 2015 Paris Climate Agreement: Outcomes and Their Impacts on Small Island States. Island Studies Journal 11 (1): 315-320.

Houghton, Katherine J., Athanasios T. Vafeidis, Barbara Neumann, and Alexander Proelss. 2010. Maritime Boundaries in a Rising Sea. Nature Geoscience 3: 813-816. DOI: https://doi.org/10.1038/ngeo1029

Kymlicka, Will. 1995. Multicultural Citizenship. Oxford, UK: Oxford University Press. DOI: https://doi.org/10.1093/0198290918.001.0001

Lazrus, Heather. 2012. Sea Change: Island Communities and Climate Change. Annual Review of Anthropology 41: 285-301. DOI: https://doi.org/10.1146/annurev-anthro $-092611-145730$

Lisztwan, Julia. 2012. Stability of Maritime Boundary Agreements. Yale Journal of International Law 37: 153-200.

Lusthaus, Jonathan. 2010. Shifting Sands: Sea Level Rise, Maritime Boundaries and Inter-state Conflict. Politics 30: 113-118. DOI: https://doi.org/10.1111/j.1467-9256.2010.01374.x

McNamara, Karen, and Carol Farbotko. 2017. Resisting a "Doomed" Fate: An Analysis of the Pacific Climate Warriors. Australian Geographer 48: 17-26. DOI: https://doi.org /10.1080/00049182.2016.1266631

Miller, David. 2007. Global Justice and National Responsibility. Oxford, UK: Oxford University Press. DOI: https://doi.org/10.1093/acprof:oso/9780199235056.003.0005

Miller, David. 2009. Global Justice and Climate Change. Tanner Lecturers on Human Values. Salt Lake City, UT: University of Utah Press.

Moellendorf, Darrel. 2002. Cosmopolitan Justice. Boulder, CO: Westview Press.

Moellendorf, Darrel. 2014. The Moral Challenge of Dangerous Climate Change. Cambridge, UK: Cambridge University Press. DOI: https://doi.org/10.1017/CBO9781139083652

Nine, Cara. 2010. Ecological Refugees, States Borders, and the Lockean Proviso. Journal of Applied Philosophy 27: 359-375. DOI: https://doi.org/10.1111/j.1468-5930.2010.00498.x

Ödalen, Jörgen. 2014. Underwater Self-Determination: Sea-Level Rise and Deterritorialized Small Island States. Ethics, Policy, and Environment 17: 225-237. DOI: https://doi.org /10.1080/21550085.2014.926086

Pacific Islands Forum Secretariat. 2010. Our Sea of Islands, Our Livelihoods, Our Oceania. Framework for a Pacific Oceanscape. Paper presented at the Pacific Islands Forum, Apia, Samoa. 
Polynesian Leaders Group. 2015. Taputapuatea Declaration on Climate Change. Papeete, July 16.

Rawls, John. 1999. The Law of Peoples. Cambridge, MA: Harvard University Press.

Rayfuse, Rosemary G. 2009. W(h)ither Tuvalu? International Law and Disappearing States. UNSW Law Research Paper 2009-9. Available at: https://papers.ssrn.com /sol3/papers.cfm?abstract_id=1412028, last accessed June 16, 2020.

Rayfuse, Rosemary. 2010. International Law and Disappearing States: Utilising Maritime Entitlements to Overcome the Statehood Dilemma. UNSW Law Research Paper 2010-52. Available at: https://papers.ssrn.com/sol3/papers.cfm?abstract_id =1704835, last accessed June 16, 2020 .

Schofield, Clive, and David Freestone. 2019. Islands Awash Amidst Rising Seas: Sea Level Rise and Insular Status Under the Law of the Sea. International Journal of Marine and Coastal Law 34: 391-414. DOI: https://doi.org/10.1163/15718085-13431098

Shue, Henry. 2014. Climate Justice: Vulnerability and Protection. Oxford, UK: Oxford University Press.

Soons, Alfred H. A. 1990. The Effects of a Rising Sea Level on Maritime Limits and Boundaries. Netherlands International Law Review 37: 207-232. DOI: https://doi .org/10.1017/S0165070X00006513

Stilz, Anna. 2019. Territorial Sovereignty: A Philosophical Exploration. Oxford, UK: Oxford University Press. DOI: https://doi.org/10.1093/oso/9780198833536.001.0001

Stoutenburg, Jenny Grote. 2015. Disappearing Island States in International Law. Boston, MA: Brill.

Titifanue, Jason, Romitesh Kant, Glen Finau, and Jope Tarai. 2017. Climate Change Advocacy in the Pacific. Pacific Journalism Review 23: 133-149. DOI: https://doi .org/10.24135/pjr.v23i1.105

Zellentin, Alexa. 2015. Climate Justice, Small Island Developing States and Cultural Loss. Climatic Change 133: 491-498. DOI: https://doi.org/10.1007/s10584-015-1410-6 